\section{Inflorescence Development in Lolium during the Arctic Summer}

DuRING a recent study of the effect of temperature and photoperiod on spikelet initiation in Lolium ${ }^{1}$, continuous artificial light supplied by 'daylight' fluorescent lamps was used for examining 'ripenessto-flower' of the shoot apex. If an apex is 'ripe-toflower', that is, competent to respond to the photo. periodic stimulus, spikelet development begins at once on exposure to continuous light. In some species, such as the Mediterranean annuals $L$. temulentum, $L$. remotum and $L$. gaudini, the shoot apex is competent immediately after germination; in others, such as $L$. italicum and most plants of $L$. rigidum, the apex eventually becomes competent, but this process is accelerated by low temperature; and in most strains of $L$. perenne competence is never attained in the absence of low temperature. presence of three leaf primordia on the shoot apex in the embryo, and production of new leaf primordia on the apex usually continues until spikelet buds are formed. This suggests that, under Arctic conditions, differentiation of spikelet buds occurred very soon after germination. Ear emergence, however, was no earlier than under artificial continuous light, suggesting that although spikelet initiation may be accelerated in the Arctic summer, subsequent elongation of the inflorescence is retarded.

Previous work ${ }^{1}$ has shown that 'daylight' fluorescent lamps and natural daylight at Aberystwyth have similar photoperiodic effects under the same temperature conditions. Differing responses to Arctic summer daylight and artificial continuous light may thus be an effect of temperature. Transplant work with $L$. perenne, to be reported later, has shown accumulated temperature to be a useful measure of the effect of temperature on rate of inflorescence

\begin{tabular}{|c|c|c|c|c|c|}
\hline & & $\begin{array}{l}\text { Lolium } \\
\text { temulentum } \mathrm{L} . \\
\text { ex Bordeaux }\end{array}$ & $\begin{array}{l}\text { Lolium } \\
\text { remotum Schrank. } \\
\text { ex Malta }\end{array}$ & $\begin{array}{l}\text { Lolium } \\
\text { gaudini Parl. } \\
\text { ex Israel }\end{array}$ & Temperatures \\
\hline \multirow{2}{*}{$\begin{array}{l}\text { Borselv, Finmark. } \\
\left(70^{\circ} 20^{\prime}, \mathrm{N} \text { ) Continuous }\right. \\
\text { natural daylight }\end{array}$} & $\begin{array}{l}\text { Germination-ear } \\
\text { emergence (days) }\end{array}$ & $39 \cdot 64 \pm 0.49$ & $40.04 \pm 0.35$ & $45.00 \pm 0.63$ & \multirow{2}{*}{$\begin{array}{l}\text { Mean max. } 69 \cdot 5^{\circ} \mathrm{F} \\
\text { Mean min. } 42 \cdot 3^{\circ} \mathrm{F} \text {. } \\
\text { Accumulated temp. } \\
556 \text { day-degrees }\end{array}$} \\
\hline & Leaf No. & $4.00 \pm 0.00$ & $3 \cdot 20 \pm 0.08$ & $4 \cdot 14 \pm 0 \cdot 10$ & \\
\hline \multirow{2}{*}{$\begin{array}{l}\text { Aberystwyth. }\left(52^{\circ} 25^{\prime} \mathrm{N} \text {.) }\right. \\
\text { Continuous artificial } \\
\text { light, indoors }\end{array}$} & $\begin{array}{l}\text { Germination-ear } \\
\text { emergence (days) }\end{array}$ & $36 \cdot 00 \pm 0.33$ & $29 \cdot 11 \pm 0.47$ & $28.00 \pm 0.57$ & \multirow{2}{*}{$\begin{array}{l}\text { Mean max. } 59 \cdot 6^{\circ} \mathrm{F} \text {. } \\
\text { Mean min. } 55 \cdot 4^{\circ} \mathrm{F} \text {. } \\
\text { Accumulated temp. } \\
620 \text { day-degrees }\end{array}$} \\
\hline & Leaf No. & $6 \cdot 10 \pm 0 \cdot 10$ & $5 \cdot 00 \pm 0 \cdot 00$ & $5 \cdot 32 \pm 0.11$ & \\
\hline \multirow{2}{*}{$\begin{array}{l}\text { Aberystwyth. }\left(52^{\circ} 25^{\prime} \mathrm{N} .\right) \\
\text { Heated greenhouse, } \\
\text { natural day-length }\end{array}$} & $\begin{array}{l}\text { Germination-ear } \\
\text { emergence (days) }\end{array}$ & $54 \cdot 82 \pm 0 \cdot 30$ & $61 \cdot 38 \pm 0 \cdot 53$ & 一 & \multirow{2}{*}{$\begin{array}{l}\text { Mean max. } 71 \cdot 3^{\circ} \mathrm{F} \text {. } \\
\text { Mean min. } 46 \cdot 8^{\circ} \mathrm{F} \text {. } \\
\text { Accumulated temp. } \\
682 \text { day-degrees }\end{array}$} \\
\hline & Leaf No. & $8.00 \pm 0.00$ & $8 \cdot 75 \pm 0.16$ & $\rightarrow$ & \\
\hline
\end{tabular}

Wach lot contained initially 20 seedlings.

The Cambridge expedition to Finmark in the summer of 1950 gave an opportunity for comparing the effects of continuous artificial light and of the continuous natural daylight of the Arctic summer. As only the photoperiodic effects were to be compared, species of Lolium were employed which respond to photoperiod very soon after germination. Three Mediterranean annual species were sown (by A. F. M..K.) at Børselv, Finmark $\left(70^{\circ} 20^{\prime}\right.$ N.), on July 7,1950 , and received continuous natural daylight until ear emergence between August 20 and 30. The $\operatorname{sam} \theta$ species were grown indoors under continuous artificial light at Aberystwyth, and two of the species were sown on March 18 in a heated greenhouse and exposed to natural day-lengths at Aberystwyth (13 hr. 12 min. on March $18-17 \mathrm{hr} .30 \mathrm{~min}$. on May 20 at date of ear emergence).

For each treatment the time from germination to ear emergence and the leaf number before heading were recorded. Daily air maximum and minimum temperatures were taken, and the accumulated temperature, in day degrees above $42^{\circ} \mathrm{F}$., calculated for the forty days after germination. Details of species sown and experimental results are given in the accompanying table.

The time from germination to ear emergence was of the same order in both artificial and natural continuous light ; but ear emergence was significantly later under Arctic conditions. In all species, however, Arctic conditions resulted in a lower leaf number before heading. In $L$. remotum, many plants headed after only three leaves, a leaf number lower than any previously obtained in Lolium. Dissection shows the development. In the present case, accumulated temperatures are similar for both treatments; but an inspection of the mean maxima and minima shows considerable daily fluctuation in the Arctic, with three minima below $32^{\circ} \mathrm{F}$. In the artificial light, an even temperature of $55-60^{\circ} \mathrm{F}$. was maintained.

In the seedlings exposed to natural day-length at Aberystwyth, time from germination to ear emergence and leaf number before heading were both greater than in the continuous-light treatments, although the photoperiod ( $13 \mathrm{hr} .12 \mathrm{~min}$.) on the sowing date was above the critical. Dissection showed spikelet initiation to be slower during the shorter photoperiods of March and April than in continuous illumination at similar temperatures. Subsequent elongation of the inflorescence was, however, equally rapid under both treatments.

These results suggest that spikelet initiation and subsequent elongation of the inflorescence may show different responses to both temperature and photoperiod.

$$
\text { J. P. COOPER }
$$

Welsh Plant Breeding Station,

University College of Wales, Aberystwyth.

(Now at Department of Agricultural Botany, University of Reading.)

Trinity College,

A. F. Money-Kyrue Cambridge.

${ }^{1}$ Cooper, J. P., J. Ecol. (in the press). 